\title{
Study of white onion (Alium cepa L.) on yield and economics under pulse irrigation (drip) for different irrigation levels
}

D. A. Madane, M. S. Mane, U. S. Kadam and R. T. Thokal

Received : 21.10.2017; Revised : 19.02.2018; Accepted : 28.02.2018

See end of the Paper for authors' affiliation Correspondence to :

\section{A. Madane}

Department of Soil Science and Agricultural Chemistry, School of Agriculture, Lovely Professional University, Punjab, India Email : dnyaneshwar.22722 @1pu.co.in
ABSTRACT : The field experiment was conducted during two Rabi seasons from $12^{\text {th }}$ November, 2014 to $26^{\text {th }}$ April, 2015 and $23^{\text {rd }}$ November, 2015 to $4^{\text {th }}$ May 2016, on sandy clay loam soil at Instructional Farm of Department of Irrigation and Drainage Engineering, College of Agricultural Engineering and Technology, Dr. Balasaheb Sawant Konkan Krishi Vidypeeth, Dapoli, India (latitude $17^{\circ} 45^{\prime} \mathrm{N}$ and longitude $73^{\circ} 10^{\prime} \mathrm{E}$ and altitude of $250 \mathrm{~m}$ ). The experiment was arranged in twelve treatment combinations with strip plot design as horizontal factor (main treatment) one continuous irrigation $\left(\mathrm{P}_{1}\right)$, two pulses $\left(\mathrm{P}_{2}\right)$, three pulses $\left(\mathrm{P}_{3}\right)$ and four pulses $\left(\mathrm{P}_{4}\right)$, while vertical factor (sub treatment) as irrigation levels viz., $\mathrm{I}_{1}\left(0.80 \mathrm{ET}_{\mathrm{C}}\right), \mathrm{I}_{2}\left(1.0 \mathrm{ET}_{\mathrm{C}}\right)$ and $\mathrm{I}_{3}\left(1.20 \mathrm{ET}_{\mathrm{C}}\right)$ treatments. It was revealed that the average seasonal water applied to white onion under pulse irrigation (drip) through different irrigation levels varied from $276.8 \mathrm{~mm}_{\text {for }} \mathrm{I}_{1}\left(0.8 \mathrm{ET}_{\mathrm{C}}\right)$ to $429.0 \mathrm{~mm}$ for $\mathrm{I}_{3}\left(1.2 \mathrm{ET}_{\mathrm{C}}\right)$ irrigation levels. Among the different treatment combination $\mathrm{I}_{2} \mathrm{P}_{4}$ (irrigation level $\mathrm{I}_{2}\left(1.0 \mathrm{ET}_{\mathrm{C}}\right)$ with four pulse treatment $\mathrm{P}_{4}$ ) was found $38.52 \mathrm{t}$ ha $\mathrm{a}^{-1}$ and significantly superior over $\mathrm{I}_{1} \mathrm{P}_{1}$ (irrigation level $\mathrm{I}_{1}\left(0.8 \mathrm{ET}_{\mathrm{C}}\right)$ with continuous irrigation $\left.\mathrm{P}_{1}\right)$. The production cost of Rs. 4,47,366 and Rs. 4,42,962 ha $^{-1}$, gross returns of Rs. 9,63,000 and Rs. 9,31,500 ha-1 net returns of Rs. 5,15,634 and Rs. 4,88,538 ha ${ }^{-1}$ and $\mathrm{B} C$ ratio of 2.15 and 2.10 , were observed for $\mathrm{I}_{2} \mathrm{P}_{4}$ and $\mathrm{I}_{3} \mathrm{P}_{4}$ treatment combinations, respectively. Average water use efficiency was found maximum for $\mathrm{I}_{1} \mathrm{P}_{4}\left(11.93 \mathrm{q} \mathrm{ha}^{-1} \mathrm{~cm}^{-1}\right)$ treatment combination followed by $\mathrm{I}_{1} \mathrm{P}_{3}\left(11.33 \mathrm{q} \mathrm{ha}^{-1} \mathrm{~cm}^{-1}\right)$ and $\mathrm{I}_{2} \mathrm{P}_{4}\left(10.99 \mathrm{q} \mathrm{ha}^{-1} \mathrm{~cm}^{-1}\right)$ treatment combinations, respectively.

- KEY WORDS : Pulse irrigation (drip), Irrigation scheduling, Water use efficiency, White onion, Cost of production, Net returns, $\mathrm{B}: \mathrm{C}$ ratio

-HOW TO CITE THIS PAPER : Madane, D.A., Mane, M.S., Kadam, U.S. and Thokal, R.T.(2018). Study of white onion (Alium cepa L.) on yield and economics under pulse irrigation (drip) for different irrigation levels. Internat. J. Agric. Engg., 11(1) : 128-134, DOI: 10.15740/HAS/IJAE/11.1/ 128-134. 